\title{
Traditional Mead “Bessoudioury" from Senegal: Process and Characterization
}

\author{
Oumar Ibn Khatab Cisse ${ }^{1,2 *}$, Bou Ndiaye ${ }^{1,2}$, Papa Guedel Faye ${ }^{1,2}$, Nicolas Cyrille Ayessou ${ }^{1,2}$, \\ Mathieu Gueye ${ }^{3}$, Mady Cisse ${ }^{1,2}$, Codou Mar Diop ${ }^{1,2}$ \\ ${ }^{1}$ Ecole Supérieure Polytechnique, Cheikh Anta Diop University, Dakar, Sénégal \\ ${ }^{2}$ Centre d'Etudes sur la Sécurité Alimentaire et les Molécules Fonctionnelles (CESAM), Dakar, Sénégal \\ ${ }^{3}$ Institut Fondamental d'Afrique Noire (IFAN), Cheikh Anta Diop University, Dakar, Sénégal \\ Email: ^oumar.cisse@esp.sn,cheikbou20@yahoo.fr,guedougui@hotmail.com,nayessou@yahoo.fr, \\ mathieu.gueye@ucad.edu.sn,mady.cisse@ucad.edu.sn,cgmare@gmail.com
}

How to cite this paper: Cisse, O.I.K., Ndiaye, B., Faye, P.G., Ayessou, N.C., Gueye, M., Cisse, M. and Diop, C.M. (2018) Traditional Mead "Bessoudioury" from Senegal: Process and Characterization. Food and Nutrition Sciences, 9, 1424-1433.

https://doi.org/10.4236/fns.2018.912103

Received: November 13, 2018

Accepted: December 25, 2018

Published: December 28, 2018

Copyright $\odot 2018$ by authors and Scientific Research Publishing Inc. This work is licensed under the Creative Commons Attribution International License (CC BY 4.0).

http://creativecommons.org/licenses/by/4.0/

(c) (i) Open Access

\begin{abstract}
Mead is a beverage obtained by alcoholic fermentation of honey, with an ethanol content of $8 \%$ to $18 \%$ by volume. In Africa, mead manufacturing methods rely on heating honey and adding extracts of fruits, herbs or spices. "Bessoudioury" mead is then prepared according to the traditional process of the Bassari and Bedick peoples of Kedougou (Senegal). This work on "Bessoudioury" aims to describe and characterize the manufacturing processes. It was also to evaluate the chemical and microbiological characteristics. The study focused on three Kedougou production sites. The manufacturing process of "Bessoudioury" includes a honey heating, a formulation step by adding wine of either Borassus aethiopicum Mart. or Elaeis guineensis. This step is followed by a fermentation's one during two days. Wine is considered as the essential sources of yeasts for the production of alcohol. "Bessoudioury" has an ethanol content of $8 \%(\mathrm{v} / \mathrm{v})$. Moulds and Streptococcus were not detected in this mead. According to its polyphenols content, this mead has a nutritional interest, but the process deserves to be reviewed to preserve nutrients.
\end{abstract}

\section{Keywords}

Honey, Mead, Fermentation, Bessoudioury

\section{Introduction}

Meads are beverages obtained by alcoholic fermentation of honey, with an ethanol content of $8 \%$ to $18 \%$ by volume [1] [2]. In Africa, bibliography indicates 
that mead would even be anterior to fermented cereal beverages. The mead was then used as a holiday drink [3] [4] [5]. In Senegal, mead is known under the name of "Bessoudioury". "Bessoudioury" (Bessou = drink, dioury = honey) is prepared according to the ancestral process of Bassari and Bedick peoples of the Kedougou's region (Senegal).

African mead-making processes typically rely on heating honey [6] and adding fruit, herb or spice extracts [7]. These methods of preparation depend on local traditions [2]. "Kuri" of Cameroon and "Ogol" of Ethiopia are prepared from artisanal starters according to ancestral practices [8] [9]. "Bessoudioury" of Kedougou (Senegal) presents a particularity that this work proposes to describe for the first time from the point of view of diagnosis as biochemical and microbiological composition.

\section{Materials and Methods}

\subsection{Diagnosis of Manufacturing Processes}

The manufacturing processes of "Bessoudioury" mead were monitored and studied at three production sites in Kedougou's region in December 2017. The process description was carried out twice at each production site. Each unit operation is identified and described. On the transformation sites, the information is then enriched by observations, records (temperature, duration), measurements (weight, volume), and interviews with operators.

\subsection{Samples of Bessoudioury Mead}

The products to be analyzed consisted of two types of meads formulated either with Borassus palm wine or palm wine. They were sent to the laboratory for biochemical and microbiological analyzes.

\subsection{Physicochemical and Biochemical Analyzes}

$\mathrm{PH}$, titratable acidity, soluble solids content, reducing and total sugars, and ethanol content were evaluated according to standard AFNOR methods [10]. The volatile acidity of "Bessoudioury" was determined according to Mathieu's method, by distillation and titration of volatile acids [11]. The total polyphenols were characterized by UV/Visible spectrophotometry (Analytik Jena, Specord 200 plus, Germany) according to the method of Georgé [12]. The color indices (browning index and yellow index) were determined by the $L^{\star} a^{\star} b$ system [13] using a Konika Minolta laboratory colorimeter (Chroma Meter C5, Japan). Antioxidant activity was determined according to the percentage inhibition of honey-based extracts on the DPPH radical [14].

\subsection{Microbiological Methods}

The microbial floras sought for the characterization are total flora, yeasts, moulds and Streptococcus. Germs were counted according to French standards [15]. 


\subsection{Statistical Analyzes}

The analysis of variance compares the significance of the difference observed between the samples analyzed according to the probability threshold of 0.05 . Principal Component Analysis (PCA) aims to define, by a geometric approach, the correlations between fermented honey extracts and physicochemical parameters. Data processing was done with Minitab software version 17.

\section{Results and Discussion}

\subsection{Traditional Bessoudioury Manufacturing Process}

The diagnosis of "Bessoudioury" process allows establishing the manufacturing diagram below (Figure 1). The method of preparation of "Bessoudioury" consists of heating the honey, a formulation step by adding Borassus palm wine or palm wine followed by fermentation.

The production of the Bassari mead begins with a $1 / 1(\mathrm{v} / \mathrm{v})$ dilution of the honey with water. The mixture then undergoes cooking for $1 \mathrm{~h} 30 \mathrm{mn}$ at a maximum temperature of $100^{\circ} \mathrm{C}$. Then, this intermediate product is cooled to $30^{\circ} \mathrm{C}$ (room temperature), ideal for the incorporation of Borassus palm wine or palm wine. Finally, this extract is stored at room temperature $\left(30^{\circ} \mathrm{C}\right)$ for a fermentation and maturation stage of 2 days (Figure 2).

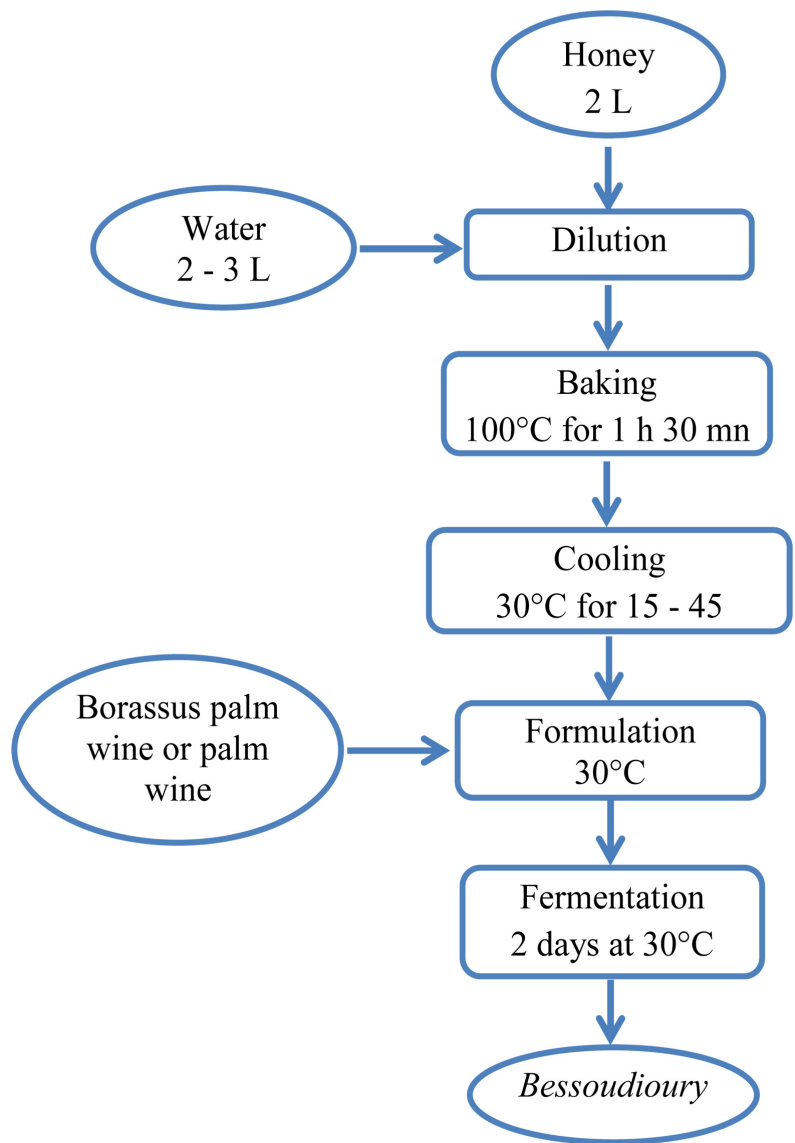

Figure 1. Production diagram of "Bessoudioury" mead. 


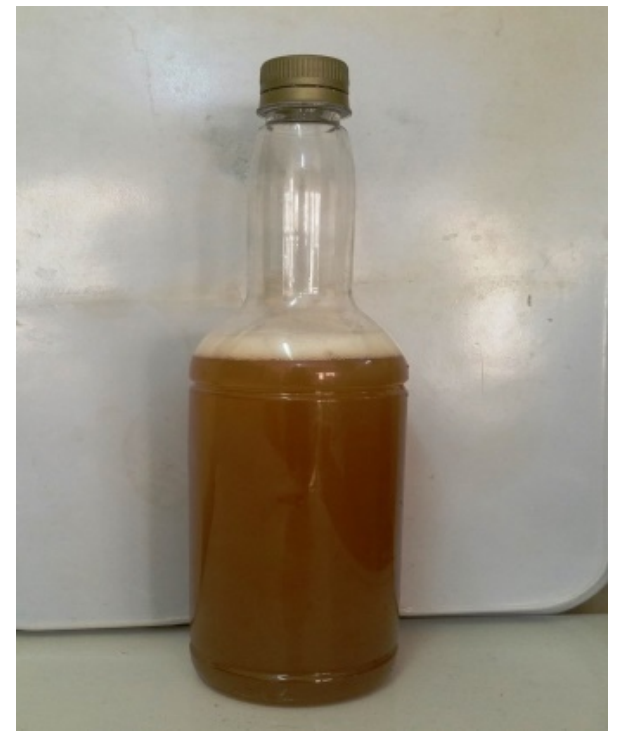

Figure 2. Bessoudioury.

African artisanal methods are essentially a dilution of honey in water, followed by a fermentation step and a clarification step [8] [16]. The dilution reduces the osmotic pressure in the honey and then favors the fermentation step by yeasts. This step is important because osmotic pressure of honey inhibits the activity of the yeasts [6]. This ratio of honey/water varies from 1/1 for "Bessoudoury", 2/5 for the Ethiopian mead "Tej" [17] and 1/3 for the Ethiopian mead "Ogol" [9]. The aim of the cooking step is to eliminate the bitterness compounds, and the autochthonous flora of honey. These flora is such us bacteria (Bacillus, Micrococcus), yeast (Saccharomyces spp.) and fungal (Aspergillus) [6]. This step certainly reduces the risk of spontaneous fermentations. Nevertherless, it may occures the degradation of the thermosensitive compounds such as the phenolic acids and the flavonoids of the honey [18]. Also, there is formation of 5-hydroxymethylfurfural (HMF) which is an intermediate product of Maillard reactions due to high temperatures [19], [20]. The duration of cooking (1 h 30 $\mathrm{mn}$ ) then justifies the low antioxidant activities compared to the Polish meads where the rate of inhibition of DPPH varies from $30 \%$ to $70 \%$ [21]. In perspective of the work, it would be necessary to optimize the cooking time of "Bessoudioury".

The water/honey mixture is inoculated with traditional leaven for 1 to 3 day fermentation at room temperature [8] [9] [17] followed by a maturation stage of 15 to 20 days for "Tej" [17] and 7 to 14 days for "Kuri" [8]. For the "Bessoudioury" production, this step of additional ferments is replaced by adding wine. In fact, yeasts are present in Borassus palm and palm wines [22] [23] [24] The presence of yeasts and lactic acid bacteria is well confirmed by our results at values of $2.4 \times 10^{5}$ at $5.8 \times 10^{6} \mathrm{CFU} / \mathrm{mL}$ for yeasts and $3.2 \times 10^{4}$ at $44 \times 10^{5}$ CFU/mL for lactic acid bacteria (Table 1). Any mould nor Streptococcus were found in "Bessoudioury". The lactic acid bacteria and yeasts counted in the 
Table 1. Microorganisms counted in fermented extracts $(\mathrm{CFU} / \mathrm{mL})$.

\begin{tabular}{ccccc}
\hline & Borassus palm wine & Palm wine & MB & MP \\
\hline Total flora & $1 \times 10^{6}$ & $1 \times 10^{5}$ & $3.2 \times 10^{5}$ & $1.6 \times 10^{5}$ \\
Lactic acid bacteria & $44 \times 10^{5}$ & $3.2 \times 10^{4}$ & $2.5 \times 10^{5}$ & $1.8 \times 10^{4}$ \\
Yeasts & $58 \times 10^{5}$ & $2.4 \times 10^{5}$ & $3.3 \times 10^{5}$ & $1.4 \times 10^{5}$ \\
Moulds & 0 & 0 & 0 & 0 \\
Streptococcus & 0 & 0 & 0 & 0 \\
\hline
\end{tabular}

CFU: colony forming unit. MB: mead "Bessoudioury" prepared with added wine Borassus palm. MP: mead "Bessoudioury" prepared with added wine palm.

wines are directly involved in the process of spontaneous fermentation of the extracts of Borassus palm and palm [24] [25] [26]. Those two types of wine are obtained by extraction and fermentation of the sap of the tree. Their ethanol concentration varies between 5.5 and 8\% (v/v) [24] [26]. Lactic acid bacteria are also involved in reducing the acidity of a wine by malolactic fermentation. Malolactic erosion accentuates the sensory profile of wine in terms of taste and aroma [27].

\subsection{Physicochemical Characteristics of the Extracts of the Manufacturing Process}

\subsubsection{Main Components of Honey}

Analysis of honey components (Table 2) confirmed its very high content of reducing sugars $(80 \mathrm{~g} / 100 \mathrm{~g})$, which is quite similar to the values found in samples of various origins: $78.9-81.2 \mathrm{~g} / 100 \mathrm{~g}$ for Romanian honey [20]; $70-73 \mathrm{~g} / 100 \mathrm{~g}$ for Brazilian honey [19]. The honey $\mathrm{pH}$ value of 4.06 is within the standard limit (pH 3.40 - 6.10) proposed by Codex Alimentarius [16]. The browning index and the brightness $L$ determined by the $L^{*} a^{*} b$ system are 16.2 and 20.82 . The comparison with the results obtained by Kus (25.05) shows a higher level of browning. The fundamental difference lies in the brightness $L$ with a value of 79.9 [18]. However, the yellow index of 18.02 is much lower compared to the Oroian data on honeys harvested in different plant species (37.6 - 57.0) [28].

The polyphenol content of the honey used for "Bessoudioury" production expressed in gallic acid equivalent is $75 \mathrm{mg} / 100 \mathrm{~g}$ ). This concentration varies from 26 to $100 \mathrm{mg} / 100 \mathrm{~g}$ in Brazilian honeys [29]; from 32.17 to $119.42 \mathrm{mg} / 100 \mathrm{~g}$ for honeys from Tunisia [30]; and $54.30 \mathrm{mg} / 100 \mathrm{~g}$ for Cuba samples [31].

\subsubsection{Physicochemical Characteristics of Bessoudioury}

"Bessoudioury" end-product with Borassus palm wine (MB1 and MB2), and one with palm wine (MP1 and MP2) were evaluated at the, biochemical levels (Table 3). All Bessoudioury samples have an acid $\mathrm{pH}$ (3.56 - 3.79) comparable to the values found in the traditional African meads "Kuri" (pH 3.0) [8], "Ogol" ( $\mathrm{pH}$ 3.8) [9], "Tej" (pH 3.02 - 4.90) [17]. There are no significant differences in terms of titratable acidity between palm and palm wines, and formulated fermented 
Table 2. Physicochemical and biochemical characteristics of honey.

\begin{tabular}{cc}
\hline Analyzes & Honey \\
\hline $\mathrm{pH}$ & $4.06 \pm 0.01$ \\
Soluble dry matter $(\mathrm{g} / 100 \mathrm{~g})$ & $81.8 \pm 0.00$ \\
Titratable acidity $(\mathrm{g}$ tartaric acid $/ 100 \mathrm{~g})$ & $1.57 \pm 0.21$ \\
Browning index & $16.46 \pm 0.36$ \\
Yellow index & $18.02 \pm 1.02$ \\
Total sugars $(\mathrm{g} / 100 \mathrm{~g})$ & $90.71 \pm 0.00$ \\
Reducing sugars $(\mathrm{g} / 100 \mathrm{~g})$ & $81.58 \pm 1.97$ \\
Polyphenols $(\mathrm{mg}$ gallic acid/100 $\mathrm{g})$ & $75.75 \pm 8.89$ \\
\hline
\end{tabular}

Table 3. Characteristics of Borassus palm wine, palm wine and meads "Bessoudioury".

\begin{tabular}{|c|c|c|c|c|c|c|}
\hline Analyzes & Borassus palm wine & Palm wine & MB1 & MB2 & MP1 & MP2 \\
\hline $\mathrm{pH}$ & $3.96 \pm 0.01^{\mathrm{a}}$ & $3.81 \pm 0.01^{\mathrm{b}}$ & $3.79 \pm 0.00^{c}$ & $3.69 \pm 0.00^{\mathrm{d}}$ & $3.57 \pm 0.01^{\mathrm{e}}$ & $3.56 \pm 0.0^{\mathrm{e}}$ \\
\hline $\begin{array}{l}\text { Soluble dry matter }(\mathrm{g} / 100 \\
\mathrm{mL})\end{array}$ & $3.15 \pm 0.07^{\mathrm{a}}$ & $3.1 \pm 0.00^{\mathrm{a}}$ & $14.85 \pm 0.07^{\mathrm{b}}$ & $19.55 \pm 0.07^{\mathrm{c}}$ & $9.5 \pm 0.00^{\mathrm{d}}$ & $9.5 \pm 0.00^{d}$ \\
\hline $\begin{array}{c}\text { Titratable acidity } \\
(\mathrm{g} \text { tartaric acid/100 } \mathrm{mL})\end{array}$ & $1.05 \pm 0.14^{\mathrm{a}}$ & $1.07 \pm 0.14^{\mathrm{a}}$ & $1.41 \pm 0.78^{\mathrm{a}}$ & $1.42 \pm 0.00^{\mathrm{a}}$ & $1.56 \pm 0.14^{\mathrm{a}}$ & $1.58 \pm 0.49^{\mathrm{a}}$ \\
\hline $\begin{array}{c}\text { Volatile acidity } \\
\left(\mathrm{g} \mathrm{H}_{2} \mathrm{SO}_{4} / 100 \mathrm{~mL}\right)\end{array}$ & $0.18 \pm 0.02^{\mathrm{a}}$ & $0.16 \pm 0.02^{\mathrm{a}}$ & $0.08 \pm 0.02^{\mathrm{b}}$ & $0.03 \pm 0.01^{b}$ & $0.18 \pm 0.01^{\mathrm{a}}$ & $0.19 \pm 0.01^{\mathrm{a}}$ \\
\hline Ethanol $(\mathrm{mL} / 100 \mathrm{~mL})$ & $2.41 \pm 0.12^{\mathrm{a}}$ & $1.49 \pm 0.11^{\mathrm{b}}$ & $8.88 \pm 0.17^{c}$ & $8.18 \pm 0.05^{\mathrm{c}}$ & $8.83 \pm 0.05^{\mathrm{c}}$ & $8.80 \pm 0.20^{c}$ \\
\hline Browning index & $14.25 \pm 0.02^{\mathrm{a}}$ & $12.23 \pm 0.02^{\mathrm{b}}$ & $48.07 \pm 0.03^{c}$ & $51.36 \pm 0.02^{\mathrm{d}}$ & $65.87 \pm 0.45^{\mathrm{e}}$ & $59.65 \pm 0.03^{\mathrm{f}}$ \\
\hline Yellow index & $16.82 \pm 0.01^{\mathrm{a}}$ & $14.59 \pm 0.01^{\mathrm{b}}$ & $46.94 \pm 0.01^{\mathrm{c}}$ & $49.03 \pm 0.01^{\mathrm{d}}$ & $56.6 \pm 0.54^{\mathrm{e}}$ & $54.87 \pm 0.07^{\mathrm{f}}$ \\
\hline Reducing sugars (g/100 mL) & $1.34 \pm 0.00^{\mathrm{a}}$ & $1.44 \pm 0.00^{\mathrm{a}}$ & $8.08 \pm 0.22^{\mathrm{b}}$ & $13.31 \pm 0.15^{\mathrm{c}}$ & $1.58 \pm 0.20^{\mathrm{a}}$ & $1.15 \pm 0.54^{\mathrm{a}}$ \\
\hline $\begin{array}{l}\text { Antioxidant activity } \\
\text { (\% inhibition) }\end{array}$ & $17.99 \pm 1.07^{\mathrm{a}}$ & $31.23 \pm 2.17^{\mathrm{b}}$ & $36.44 \pm 0.35^{\mathrm{c}}$ & $43.76 \pm 0.76^{\mathrm{d}}$ & $41.68 \pm 1.09^{\mathrm{d}}$ & $29.98 \pm 1.61^{\mathrm{b}}$ \\
\hline $\begin{array}{c}\text { Polyphenols } \\
(\mathrm{mg} \text { gallic acid } / 100 \mathrm{~mL})\end{array}$ & $38.08 \pm 0.75^{\mathrm{a}}$ & $46.67 \pm 15.29^{a . b}$ & $76.60 \pm 7.48^{c}$ & $65.24 \pm 0.88^{b . c}$ & $103.71 \pm 8.23^{\mathrm{d}}$ & $76.41 \pm 0.84^{c}$ \\
\hline
\end{tabular}

MB1: mead "Bessoudioury" prepared with added wine Borassus palm, first production. MB2: mead "Bessoudioury" prepared with added wine Borassus palm, second production. MP1: mead "Bessoudioury" prepared with added wine palm, first production. MP2: mead "Bessoudioury" prepared with added wine palm, second production. ${ }^{\mathrm{a}, \mathrm{b}, \mathrm{c}}$ : values in columns labeled with different letters are significantly different $(\mathrm{p}<0.05)$.

Bessoudioury. However, meads with the addition of Borassus palm wine (MB1 and MB2) have volatile acidity (0.03 - 0.08), much lower than those formulated with palm wine $(0.18$ - 0.19). "Bessoudioury" has an ethanol content of $8 \%(\mathrm{v} / \mathrm{v})$, lower than that found in the traditional "Kuri" meads of Cameroon $(15.4 \%$ according to [8]; Ethiopia (16.5\% - 17.5\% for "Ogol" [9]; 6.98\% - 10.9\% for "Tej" according to [17] and of South Africa (11.92 - 12.03 for "iQhilika" according to [2].

Traditionally fruits and herbal extracts are used to impart particular flavors and tastes, but in the case of mead it seems not masking the flavor of honey [6]. The incorporation of Borassus palm and palm wines is therefore essential for the sensory qualities sought in "Bessoudioury". In addition, researches on mead had already established different strains of Saccharomyces cerevisiae tested for their 
resistance to high concentrations of ethanol and the osmotic stress of honey [32] [33]. These strains, quite similar to those used in oenology, are responsible for the biotransformation of glucose and fructose, in ethanol and carbon dioxide [6]. The volatile acidities established in Bessoudioury beverages, lower than acceptable limits in oenology [32], corroborate the hypothesis of a single alcoholic fermentation. This further confirms its sanitary and organoleptic quality. The acid $\mathrm{pH}(\mathrm{pH}=3)$ of both wines and finished mead is incompatible with the growth of most microorganisms. To this is added the bactericidal and antifungal effect of ethanol.

The polyphenol concentrations of "Bessoudioury" (65.24 - $103.71 \mathrm{mg} / 100 \mathrm{~g})$ prove their best nutritional benefits compared to wines $(38.08-46.67 \mathrm{mg} / 100 \mathrm{~g})$. The high antioxidant activities confirm it well (29.98\% - 43.76\%). Antioxidant capacity is the main physiological role attributed to polyphenols. The antioxidant action of a phenolic compound can result from a combination of chemical events, including enzymatic inhibition, metal chelation, hydrogen donation and oxidation to a stable radical. In the body, free radicals are at the root of much oxidative degradation of macromolecules such as DNA and lipids. Polyphenols can act as antioxidants in different ways. By inhibiting the potential for cell and lipid degradation generated by free radicals, polyphenols would play a role in the protection against degenerative diseases, certain cancers and cardiovascular diseases [34] [35] [36].

The factorial design of the principal component analysis confirmed the three classes of products studied (Borassus palm and palm wines, MB1/MB2, MP1/MP2). Positive correlations were established between "Bessoudioury" and polyphenols, antioxidant activity and color indices. However, the correlation is stronger for drinks made by adding palm wine. The meads MP1 and MP2 also have a closer dependence on the volatile acidity along the second dimension of the factorial plane (Figure 3).

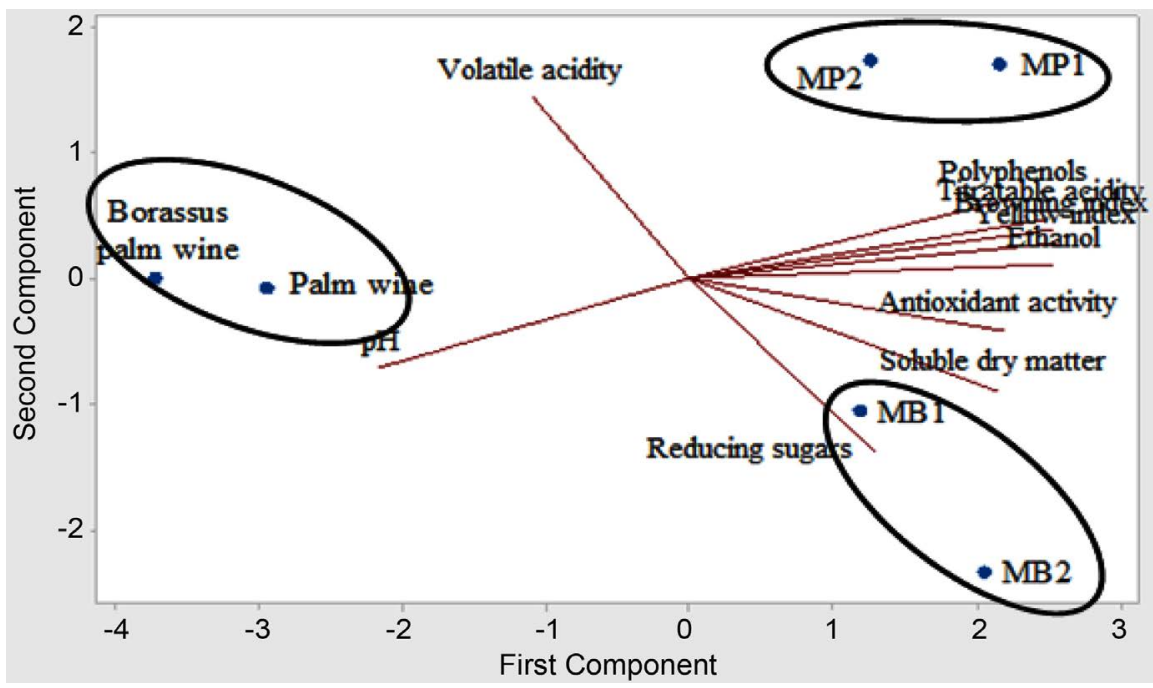

Figure 3. Correlation between the physicochemical parameters and the extracts analyzed according to the first two dimensions of the principal components analysis. 
The two formulations of the Bassari mead of Kedougou (Senegal) follow the availability of raw materials (Borassus palm or palm wines). "Bessoudioury" was originally the main drink shared during religious ceremonies and rites of passage. Today, the production of this mead has become an income-generating activity for many local households. The information gathered from producers and consumers, however, indicates a preference for "Bessoudioury" prepared with Borassus palm wine.

\section{Conclusion}

This traditional drink has an alcohol content of $8 \%(\mathrm{v} / \mathrm{v})$ and a high concentration of polyphenols $(65-103 \mathrm{mg} / 100 \mathrm{~mL}$ ). The manufacturing process of "Bessoudioury" has some differences compared to other African meads. The Borassus palm wine and palm wines added during fermentation bring particular flavors to the end product. This work has provided a better understanding of this honey-based drink and advice to investigate genomic aspect of its microbial flora.

\section{Conflicts of Interest}

The authors declare no conflicts of interest regarding the publication of this paper.

\section{References}

[1] Mendes-Ferreira, A., Cosme, F., Barbosa, C., Falco, V., Inês, A. and Mendes-Faia, A. (2010) Optimization of Honey-Must Preparation and Alcoholic Fermentation by Saccharomyces cerevisiae for Mead Production. International Journal of Food Microbiology, 144, 193-198. https://doi.org/10.1016/j.ijfoodmicro.2010.09.016

[2] Šmogrovičová, D., Nádaskỳ, P., Tandlich, R., Wilhelmi, B.S. and Cambray, G. (2012) Analytical and Aroma Profiles of Slovak and South African Meads. Czech Journal of Food Sciences, 30, 241-246. https://doi.org/10.17221/113/2011-CJFS

[3] Chrétien, J.-P. and Mworoha, E. (1970) Tombs of the Bami of Burundi: An Aspect of the Sacred Monarchy in East Africa. Cahiersd études Africaines, 10, 40-79.

[4] Huetz de Lemps, A. (2001) Beverages and Civilizations in Africa. University Presses of Bordeaux. University of Bordeaux 3, France, 665.

[5] Saitoti, E.O. (1980) The Masai. Du Chêne, Paris, France, 276.

[6] Ramalhosa, E., Gomes, T., Pereira, A.P., Dias, T. and Estevinho, L.M. (2011) Mead Production. Advances in Food and Nutrition Research, 63, 101-118. https://doi.org/10.1016/B978-0-12-384927-4.00004-X

[7] McConnell, D.S. and Schramm, K.D. (1995) Mead Success: Ingredients, Processes and Techniques. Zymurgy Spring, 4, 33-39.

[8] Roger, D.D., Daoudou, B., James, B. and Etoa, F. (2014) Artisanal Production of "Kuri" an Honey Made Alcoholic Beverage from Adamaoua Cameroon. Global Journal of Scientific Researches, 2, 65-70.

[9] Teramoto, Y., Sato, R. and Ueda, S. (2005) Characteristics of Fermentation Yeast Isolated from Traditional Ethiopian Honey Wine, Ogol. African Journal of Biotechnology, 4, 160-163.

[10] French Association of Normalization (AFNOR) (1982) Products Derived from Fruit 
and Vegetable Juices. $1^{\text {st }}$ Edition, AFNOR, Paris, France, 327.

[11] Ribereau-Gayon, J. and Peynaud, E. (1958) Analysis and Control of Wines. Polytechnic Beranger. Paris, France, 756.

[12] Georgé, S., Brat, P., Alter, P. and Amiot, M.J. (2005) Rapid Determination of Polyphenols and Vitamin C in Plant-Derived Products. Journal of Agricultural and Food Chemistry, 53, 1370-1373. https://doi.org/10.1021/jf048396b

[13] French Association of Normalization (AFNOR) (2011) Colorimetry Part 4: Chromatic Space $L^{*} a^{*} b$ CIE 1976. $1^{\text {st }}$ Edition, AFNOR, Paris, France, 8.

[14] Ozgen, M., Reese, R.N., Tulio, A.Z., Scheerens, J.C. and Miller, A.R. (2006) Modified 2,2-Azino-Bis-3-Ethylbenzothiazoline-6-Sulfonic Acid (Abts) Method to Measure Antioxidant Capacity of Selected Small Fruits and Comparison to Ferric Reducing Antioxidant Power (FRAP) and 2,2'-Diphenyl-1-Picrylhydrazyl (DPPH) Methods. Journal of Agricultural and Food Chemistry, 54, 1151-1157. https://doi.org/10.1021/jf051960d

[15] French Association of Normalization (AFNOR) (2013) Microbiology of Food and Animal Feeding Stuffs: Horizontal Method for the Enumeration of Micro-Organisms. $1^{\text {st }}$ Edition, AFNOR, Paris, France, 9.

[16] Codex Alimentarius (2001) Draft Revised Standard for Standard for Honey (at Step 10 of the Codex Procedure). Alinorm, 1, 19-26.

[17] Bahiru, B., Mehari, T. and Ashenafi, M. (2001) Chemical and Nutritional Properties of tej, an Indigenous Ethiopian Honey Wine: Variations within and between Production Units. Journal of Food Technology in Africa, 6, 104-108.

[18] Kuś, P.M., Jerković, I., Marijanović, Z., Kranjac, M. and Tuberoso, C.I.G. (2018) Unlocking Phacelia tanacetifolia Benth. Honey Characterization through Melissopalynological Analysis, Color Determination and Volatiles Chemical Profiling. Food Research International, 106, 243-253. https://doi.org/10.1016/j.foodres.2017.12.065

[19] do Nascimento, K.S., Gasparotto Sattler, J., Lauer Macedo, L., Serna González, C. and Pereira de Melo, I. (2018) Phenolic Compounds, Antioxidant Capacity and Physicochemical Properties of Brazilian Apis mellifera Honeys. LWT, 91, 85-94.

[20] Oroian, M. and Ropciuc, S. (2017) Honey Authentication Based on Physicochemical Parameters and Phenolic Compounds. Computers and Electronics in Agriculture, 138, 148-156. https://doi.org/10.1016/j.compag.2017.04.020

[21] de Almeida, A.M.M., Oliveira, M.B.S., da Costa, J.G., Valentim, I.B. and Goulart, M.O.F. (2016) Antioxidant Capacity, Physicochemical and Floral Characterization of Honeys from the Northeast of Brazil. Revista Virtual de Química, 8, 57-77.

[22] Amoa-Awua, W.K., Sampson, E. and Tano-Debrah, K. (2007) Growth of Yeasts, Lactic and Acetic Acid Bacteria in Palm Wine during Tapping and Fermentation from Felled Oil Palm (Elaeis guineensis) in Ghana. Journal of Applied Microbiology, 102, 599-606. https://doi.org/10.1111/j.1365-2672.2006.03074.x

[23] Bassir, O. (1962) Observations on the Fermentation of Palm Wine. West African Journal of Biological Chemistry, 6, 20-25.

[24] Tapsoba, F., Savadogo, A., Somda, K.M., Zongo, C. and Barro, N. (2011) Microbial Biodiversity and Physicochemical Parameters of Some borassus Wines (Borassus akeassii) Traditionally Produced in Burkina Faso. Revue de Microbiologie Industrielle, Sanitaire, et Environnementale, 5, 1-22.

[25] Nwachukwu, I., Ekaiko, M.U. and Stephen, C. (2016) Microbiological Quality of Palm Wine (Elaeis guineensis and Raphia hookeri) Sold within Aba Metropolis, Abia State, South Eastern Nigeria. European Journal of Biotechnology and Genetic 
Engineering, 3, 38-44.

[26] Santiago-Urbina, J.A. and Ruíz-Terán, F. (2014) Microbiology and Biochemistry of Traditional Palm Wine Produced around the World. International Food Research Journal, 21, 1261-1269.

[27] Alexandre, H., Grandvalet, C., Guilloux-Benatier, M., Remize-Barnavon, F. and Tourdot-Maréchal, R. (2008) Lactic Bacteria in Oenology. Tec \& Doc Lavoisier, Paris, 172.

[28] Rao, P.V., Krishnan, K.T., Salleh, N. and Gan, S.H. (2016) Biological and Therapeutic Effects of Honey Produced by Honey Bees and Stingless Bees: A Comparative Review. Revista Brasileira de Farmacognosia, 26, 657-664. https://doi.org/10.1016/j.bjp.2016.01.012

[29] Boussaid, A., Chouaibi, M., Rezig, L., Hellal, R., Donsì, F., Ferrari, G. and Hamdi, S. (2018) Physicochemical and Bioactive Properties of Six Honey Samples from Various Floral Origins from Tunisia. Arabian Journal of Chemistry, 11, 265-274. https://doi.org/10.1016/j.arabjc.2014.08.011

[30] Tosi, E., Ciappini, M., Ré, E. and Lucero, H. (2002) Honey Thermal Treatment Effects on Hydroxymethylfurfural Content. Food Chemistry, 77, 71-74. https://doi.org/10.1016/S0308-8146(01)00325-9

[31] da Silva, P.M., Gauche, C., Gonzaga, L.V., Costa, A.C.O. and Fett, R. (2016) Honey: Chemical Composition, Stability and Authenticity. Food Chemistry, 196, 309-323. https://doi.org/10.1016/j.foodchem.2015.09.051

[32] International Organization of Vine and Wine (OIV) (2015) Maximum Acceptable Limits. In: Collection of International Methods of Analysis of Wines and Musts, OIV, Paris, 6.

[33] Pereira, A.P., Dias, T., Andrade, J., Ramalhosa, E. and Estevinho, L.M. (2009) Mead Production: Selection and Characterization Assays of Saccharomyces cerevisiae Strains. Food and Chemical Toxicology, 47, 2057-2063. https://doi.org/10.1016/j.fct.2009.05.028

[34] Hennebelle, T., Sahpaz, S. and Bailleul, F. (2004) Plant Polyphenols, Sources, Uses and Potential in the Fight against Oxidative Stress. Phytotherapie, 2, 3-6. https://doi.org/10.1007/s10298-004-0003-8

[35] Mukhtar, H. and Ahmad, N. (2000) Tea Polyphenols: Prevention of Cancer and Optimizing Health. The American Journal of Clinical Nutrition, 71, 1698S-1702S. https://doi.org/10.1093/ajcn/71.6.1698S

[36] Scalbert, A., Johnson, I.T. and Saltmarsh, M. (2005) Polyphenols: Antioxidants and Beyond. The American Journal of Clinical Nutrition, 81, 215S-217S. https://doi.org/10.1093/ajcn/81.1.215S 